\title{
THE ESSENCE OF PENSION PROVISION AS A COMPONENT OF THE SOCIAL PROTECTION SYSTEM IN UKRAINE
}

\author{
Anastasiia Hnidets ${ }^{1}$, Tetyana Shapovalova ${ }^{2}$ \\ Lviv Polytechnic National University, Lviv, Ukraine \\ ${ }^{1}$ Student of bachelor program "Social Welfare", of Department of Sociology and Social Work, \\ ${ }^{2}$ Candidate of economic sciences, Docent of Department of Sociology and Social Work
}

Background: The socio-economic situation in Ukraine leaves the issue of providing social guarantees to the population very painful. The current pension system, unfortunately, is unable to provide people who are entitled to a decent retirement life by law and therefore need careful review and reform.

Purpose: Describe and investigate the nature of retirement provision as a major and important component of the social protection system in Ukraine.

Methods: This research was based on general scientific methods, including content analysis, which analyzed pension in Ukraine.

Results: The basic system of social protection in Ukraine is the pension provision of the population, it includes unemployed elderly people, people with disabilities, people who have lost a breadwinner; There is state social assistance for persons entitled to a pension and persons with disabilities.

Conclusion: It should be noted that in Ukraine the pension system operates at a sufficiently satisfactory level, it satisfies the needs of people of retirement age and people who are entitled to a pension in accordance with applicable legislation at the basic level. the

At present, it is imperfect and must undergo a long-lasting reform process to improve it. The state must do everything to successfully reform the pension system.

There is a single, possible way for our country to create a stronger pension system, make it fully transparent, and demonstrate to participants how this system should protect their interests and rights in real life. It also needs to be thoroughly revised and refined, and a holistic three-tier system implemented. How well it will be planned and executed, starting with the work with the legislative framework, the main institutions and infrastructure and ending with the training of the competence of the personal financial institutions and state regulatory bodies, depends on the quality of all services in the future.

Key words: pension system, social protection, pension provision, pension right.

Варто наголосити на тому, що пенсійне забезпечення можна рахувати головною складовою соціального забезпечення, воно відповідає за стабільний розвиток населення, а також характеризується як базова і важлива гарантія забезпечення гідного рівня життя, так як воно охоплює інтереси працездатної та непрацездатної частини всього населення. Можна зазначити, що пенсійне забезпечення розглядається як особливий складовий елемент соціальної функції держави, а також, його можна охарактеризувати як комлекс методів задоволення матеріальних потреб тих верств населення, які, відповідно до чинного законодавства, мають право на отримання такого роду допомоги, тобто пенсії.

Таким чином, пенсійне забезпечення $є$ також i домінуючою складовою соціального забезпечення населення і виступає чинником який задовільняє вимоги та права людей похилого віку, які отримують пенсії, та категорії населення, які мають на неї право, відповідно до чинного законодавства.

Пенсійне забезпечення є фрагментом економічної системи України, а правовідносини у сфері пенсійного забезпечення - це правові зв'язки, які дозволяють йому не просто існувати, але й ефективно функціонувати. (Луговенко, 2005)

Пенсійні права - це одні з основних соціальних прав людини, які визначені Конституцією України, міжнародними правовими актами, законами України. Ці права не просто проголошені чи задекларовані, Правильна реалізація цих прав є одним із найважливіших 
завдань предмету права соціального забезпечення та органів державної влади, що здійснюють правореалізацію у цій сфері. (Шумило, 2011)

Пенсійним забезпеченням являється саме матеріальне забезпечення, яке надається 3 Пенсійного фонду України та Державного бюджету відповідно до діючого законодавства правил особам пенсійного віку і непрацездатним громадянам, а також тим, які втратили годувальника з огляду на визнану суспільством об'єктивно існуючу необхідність надавати таким громадянам утримання за рахунок коштів, асигнованих на ці цілі державою.

Це поняття є достатньо повним, так як визначає суб'єктів та об'єктів пенсійного забезпечення.

У статті зазначаємо, що пенсійне забезпечення є основною складовою державної системи соціального захисту населення і безумовно, відображає характерні ознаки цієї вищої системи, яка представляє собою систему взаємопов'язаних грошових фондів, органів та установ, суб'єктів забезпечення, видів забезпечення та правових актів.

На основі наведених визначень до основних характерних ознак пенсійного забезпечення належать:

- регулярні грошові платежі;

- кошти на виплату пенсій виділяються із спеціально створених для цього фондів;

- розмір пенсії призначається особисто для кожної людини;

- пенсії призначаються від настання пенсійного віку, наявністю трудового стажу або з непрацездатністю людини чи втратою годувальника. (Лібанова, 2006)

Варто зазначити, що система пенсійного забезпечення в Україні складається 3 трьох рівнів.

Система, яка складається з трьох рівнів дозволяє розподілити між всіма їі складовими ризики, що пов'язані із змінами в демографічній ситуації (що притаманне солідарній системі) і 3 коливаннями в економіці та на ринку капіталів (що більш відповідає накопичувальній системі). Саме цей розподіл всіх ризиків дозволяє підтримувати фінансову збалансованість та стійкість пенсійної системи, що застраховує населення від зменшення загального рівня доходів після виходу на пенсію і $\epsilon$ надзвичайно важливим для всіх пенсіонерів, та людей які мають право на пенсію.

Солідарна система та обов`язкова накопичувальна система належать до загальнообов'язкового державного пенсійного страхування. Обов`язкова накопичувальна система та система добровільного недержавного пенсійного забезпечення становлять систему накопичувального пенсійного забезпечення. Кожен громадянин України може бути одночасно учасником різних рівнів пенсійної системи.

Нажаль в Україні діють лише перші два рівні системи пенсійного забезпечення, про те ефективніше було б зробити цілісну трирівневу систему, для покращення загальної ситуації.

Система пенсійного забезпечення є однією з основних гарантій якісного соціального захисту, його зміст полягає, перш за все в підтримці матеріального добробуту громадян та їх сімей при виході на пенсію за віком, інвалідністю або у зв язку з втратою годувальника.

Зміст пенсійного забезпечення можна визначити як систему інститутів (організацій i правил) та механізмів їх взаємодії, що акумулюють кошти через розподільчий (оподаткування) та нагромаджувальний (страхування) канали, амортизують наслідки прогнозованих соціальних ризиків (зміна матеріального становища працюючих та інших категорій громадян внаслідок настання старості, інвалідності, втрати годувальника) у відповідності до визначених соціальних технологій та національних правил, які мінімізують наслідки зміни матеріального становища.(Мастюгіна, 2012)

Виходячи $з$ вище сказаного слід наголосити на тому. що національні моделі пенсійних систем відрізняються перш за все різноманіттям інститутів соціального захисту: обов'язкове соціальне страхування, державне соціальне забезпечення, особисте пенсійне страхування, накопичувальні пенсійні програми, розподільчі системи, пенсійні плани 3 встановленим розміром внесків, пенсійні плани з встановленим розміром допомог та інші. 
Загалом, система пенсійного забезпечення за своєю структурою та змістом є доволі складним і непростим комплексом економічних відносин та фінансових механізмів, 3 їх допомогою виконується формування і використання Пенсійного фонду. Також формуються певні умови для пенсійного забезпечення категорій населення, які відповідно до діючого законодавства мають на це право. Пенсійна політика керує пенсіним забезпеченням в Україні, а також має внлики вплив на нього. ÏÏ зміст залежать не тільки від фінансовоекономічних можливостей держави, але й від соціальних інтересів населення, мотивації уряду, ідеології і політики правлячих партій та активності громадянського суспільства.

\section{Список використаних джерел}

Лібанова, Е. (2006) Оплата праці та пенсійне забезпечення в Україні. Національна безпека $i$ оборона, 12, 114-116.

Луговенко, Н. (2005)Соціальні функції пенсійного забезпечення. Вісник академї державного управління при Президентові України, 4, 420-423.

Мастюгіна, Г. (2012)Пенсійне забезпечення. Вісник податкової служби України, 3, 44-46.

Шумило,М. (2011) Сучасний стан пенсійного законодавства в Україні. Соиіальне ma пенсійне право, 4, 38-40.

\section{References}

Libanova, E. (2006) Wages and pensions in Ukraine. National Security and Defense, 12, 114-116.

Lugovenko, N. (2005) Social functions of pension provision. Bulletin of the Academy of Public Administration under the President of Ukraine, 4, 420-423.

Mastyugina, G. (2012) Retirement provision. Bulletin of the Tax Service of Ukraine, 3, 44-46.

Shumilo, M. (2011) Current state of pension legislation in Ukraine. Social and Pension Law, 4, 3840.

\section{Contact information:}

Анастасія Гнідець

nastagnidec00@gmail.com 